\title{
Assessment of PBND and PSND Tolerant Groundnut Variety Kadiri Amaravathi
}

\author{
R. Prasanna Lakshmi ${ }^{1 *}$, P. Ganesh Kumar1 , P. Lavanya Kumari², \\ M. Reddi Kumar ${ }^{1}$ and M. Kishan Tej ${ }^{3}$ \\ ${ }^{1}$ Krishi Vigyan Kendra, Kalikiri, Chittoor District, India \\ ${ }^{2}$ Regional Agricultural Research Station, Tirupati, India \\ ${ }^{3}$ District Agricultural Advisory and Transfer of Technology Centre, Kalikiri, Acharya N G \\ Ranga Agricultural University, Guntur, Andhra Pradesh, India \\ *Corresponding author
}

\begin{tabular}{|c|c|}
\hline & A B S T R A C T \\
\hline & Groundnut is the major oilseed crop in Chittoor district of Andhra Pradesh grown in \\
\hline Keywords & $\begin{array}{l}1,40,000 \text { ha during kharif and rabi seasons. PBND and PSND are major problems in } \\
\text { groundnut cultivation causing yield losses to the farmers. On Farm Trial on assessment of }\end{array}$ \\
\hline $\begin{array}{l}\text { Groundnut, PBND, } \\
\text { PSND, Varietal }\end{array}$ & $\begin{array}{l}\text { PBND and PSND tolerant groundnut variety Kadiri Amaravathi was conducted during } \\
\text { rabi, 2018-19. In Kadiri Amaravathi variety } 3.4-22.1 \% \text { thrips damage was recorded. }\end{array}$ \\
\hline $\begin{array}{l}\text { tolerance, Kadiri } \\
\text { Amaravathi }\end{array}$ & $\begin{array}{l}\text { Whereas in Narayani variety } 8.2 \text { to } 35.7 \% \text { damage was recorded. Thrips damage was more } \\
\text { at } 80-100 \text { DAS i.e. during February and March months. Incidence of PBND \& PSND was }\end{array}$ \\
\hline Article Info & $\begin{array}{l}\text { low during the season in both the varieties. In Kadiri Amaravathi } 0.08 \% \text { and } 0.22 \% \text { of } \\
\text { PBND \& PSND was noticed whereas in Naravani } 4.06 \% \text { and } 4.49 \% \text { of PBND \& PSND }\end{array}$ \\
\hline $\begin{array}{l}\text { Accepted: } \\
12 \text { May } 2019 \\
\text { Available Online: } \\
10 \text { June } 2019\end{array}$ & $\begin{array}{l}\text { was recorded. Though thrips damage was recorded up to } 20-35 \% \text { in both the varieties, } \\
\text { PBND and PSND damage was low. Absence of Thrips palmi, vector of viral diseases } \\
\text { might be the reason for low incidence of viral diseases. Average yield of Kadiri } \\
\text { Amaravathi variety }(2500 \mathrm{~kg} / \mathrm{ha} \text { ) was } 20.6 \% \text { low than Narayani variety ( } 3150 \mathrm{~kg} / \mathrm{ha}) \text { during }\end{array}$ \\
\hline & \\
\hline
\end{tabular}

\section{Introduction}

Groundnut is an important oilseed crop in India occupying an area of $4.56 \mathrm{~m}$.ha with production of $6.77 \mathrm{mt}$ and $1486 \mathrm{~kg} / \mathrm{ha}$ productivity. Gujarat, Andhra Pradesh, Tamilnadu, Karnataka, Maharashtra and Rajasthan are the major groundnut growing states contributing $90 \%$ of the total production. Andhra Pradesh accounting for
$17 \%$ of area and $11.8 \%$ production (Anon, 2017). Anantapur district is the largest producer in the state with a production of $0.11 \mathrm{mt}$ from an area of $0.89 \mathrm{~m}$.ha followed by Chittoor district.

Groundnut crop suffers from various biotic and abiotic stresses causing heavy yield losses. Among biotic stresses insect pests, diseases pose serious threat to groundnut 
production. Among the sap feeders attacking groundnut crop, thrips species occur as a complex and causes damage from vegetative to harvesting stage (Vijayalakshmi et al., 2009). Nymphs and adults inhabit younger leaves and flowers and cause direct loss by scraping chlorophyll content of leaves and indirect loss by transmitting viral diseases like Peanut Bud Necrosis Disease (PBND) and Peanut Stem Necrosis Disease (PSND) in persistent and propagative manner (Ulman et al., 1997).

Four species of thrips, Scirtothrips dorsalis Hood, Frankliniella schultzei Trybom, Thrips palmi Karny and Caliothrips indicus (Bagnall) (Nandagopal and Vasanta, 1991; Ranga Rao and Wightman, 1993) are known to occur in groundnut and they can cause yield loss up to 17 to 40 percent (Ghewande, 1987). Thrips palmi plays a major role in transmitting the viral diseases.

More than 55 pathogens have been reported to affect Groundnut crop (Ghewande et al., 2002). PBND is the major disease in groundnut causing economic yield losses to the farmers. The disease can cause yield losses of over 50 percent and its incidence ranges from 5 to 80 percent in all major groundnut growing areas of India (Ghanekar et al., 1979; Reddy et al., 1983). The yield loss will due to PBND in groundnut mainly depend on the time of infection. If infection occurs on young plants i.e. before 60DAS the loss will be $100 \%$. If it occurs after plant starts producing pods, loss will be minimal (Gopal and Upadhyaya, 1980). To control PBND, management of the vector i.e. thrips is the only option. But control of thrips is relied on application of insecticides, and frequent chemical sprays are needed to control thrips. Several thrips species are capable of developing resistance to insecticides (Daughtrey et al., 1997; Immaraju et al., 1992).
Hence, growing of genotypes having resistance/tolerance to the disease is economically and environmentally safe and useful in minimizing yield losses to the farmers. In this connection, On Farm Trial (OFT) was conducted to assess the performance of PBND and PSND tolerant groundnut genotype Kadiri Amaravathi for disease tolerance and yield against local check i.e. Narayani.

\section{Materials and Methods}

Groundnut is the major oilseed crop in Chittoor district of Andhra Pradesh grown in an area of 1,25,000ha during kharif and 12,000ha during rabi. Kadiri-6 is the predominant variety during kharif and Narayani variety is grown in few parts of district during rabi. OFT on PBND \& PSND tolerant groundnut variety Kadiri Amaravathi was conducted during rabi, 2018-19 in 4 locations at farmers fields. Groundnut variety Narayani is taken as check in all the locations and data was collected at 20days interval from vegetative stage to harvesting stage. Groundnut variety Kadiri Amaravathi is bold seeded variety with dark green foliage, pink seed testa and 130days duration.

It can be grown during kharif, rabi and summer. Narayani is a red testa variety with light green foliage and 110days duration.

Crop was sown during last week of November, 2018 in all locations. Harvesting of check variety Narayani was completed by $2^{\text {nd }}$ week of March, 2019 and Kadiri Amaravathi was harvested during $2^{\text {nd }}$ week of April, 2019.

Data on percent damage by thrips, PBND and PSND was collected at regular intervals. Data was collected from 20DAS to late stage of the cropping season. In unit area, five spots of $1 \mathrm{~m}^{2}$ area were randomly selected. No. of 
plants showing symptoms of thrips damage, PBND \& PSND damage were counted out of total plants. Percent damage was worked out for each period of observation for individual fields.

Number of PBND/PSND plants Per cent Disease $(\%)=$

Total number of plants

\section{Results and Discussion}

\section{Incidence of thrips}

Data on mean percent damage by thrips during Rabi, 2018-19 indicate that thrips incidence was less in Kadiri Amaravathi when compared to Narayani. Minimum incidence of $3.4 \%$ and maximum of $22.1 \%$ was noticed in Kadiri Amaravathi whereas in Narayani 8.2 to $35.75 \%$ was recorded.

Thrips damage was scored as per the scale given by Keerati - Kasikorn and Singha, 1986. Kadiri Amaravathi variety fall under the scale of 3 whereas Narayani variety under 5. Because of its dark green foliage Kadiri Amaravathi variety might be recorded less damage by thrips when compared to Narayani variety which has light green foliage. Amin (1985) reported that resistance to thrips in groundnut is associated with dark green leaf colour. Dwivedi et al., (1993) also reported close association between resistance to thrips and dark green leaf colour, leaf wax and trichomes in groundnut variety ICGV-86031.

Thrips incidence was started from 20DAS and continued till harvest in both the varieties. The incidence was more during 80-100DAS i.e. from $2^{\text {nd }} \mathrm{FN}$ of February to $2^{\text {nd }} \mathrm{FN}$ of March. Increased temperatures at later stages of crop might be favoured thrips population buildup thereby the damage was more during pegging to pod development stages in both the varieties. The results are in accordance with Vijaya lakshmi et al., (2017) who reported the higher incidence of thrips during February and March during rabi season. Harish et al., (2014) reported that the populations of leafhopper and thrips had a direct and significant relationship with maximum temperature and sunshine hours but non-significant relation with minimum temperature (Table 1).

\section{Incidence of viral diseases}

\section{Peanut Bud Necrosis Disease (PBND)}

PBND incidence was less during the season. In Kadiri Amaravathi variety damage was noticed during 40DAS $(0.4 \%)$ then the damage was not observed. Whereas in Narayani variety a minimum of $2.28 \%$ to maximum of $5.4 \%$ was recorded. The damage was in increasing state from vegetative stage to harvesting stage (Table 2).

Table.1 Percent damage by thrips

\begin{tabular}{|c|c|c|c|c|}
\hline \multirow{2}{*}{ Days } & \multicolumn{2}{|c|}{ Mean } & \multicolumn{2}{c|}{ Std. Deviation } \\
\cline { 2 - 5 } & Kadiri Amaravathi & Narayani & Kadiri Amaravathi & Narayani \\
\hline 20 DAS & 4.20 & 8.20 & 0.42 & 4.95 \\
\hline 40 DAS & 3.45 & 14.42 & 2.48 & 0.30 \\
\hline 60 DAS & 14.60 & 31.55 & 15.98 & 11.24 \\
\hline 80 DAS & 16.90 & 34.35 & 13.15 & 9.13 \\
\hline 100 DAS & 22.10 & 35.75 & 8.77 & \\
\hline Average & $\mathbf{1 2 . 2 5}$ & $\mathbf{2 4 . 8 5}$ & & \\
\hline
\end{tabular}




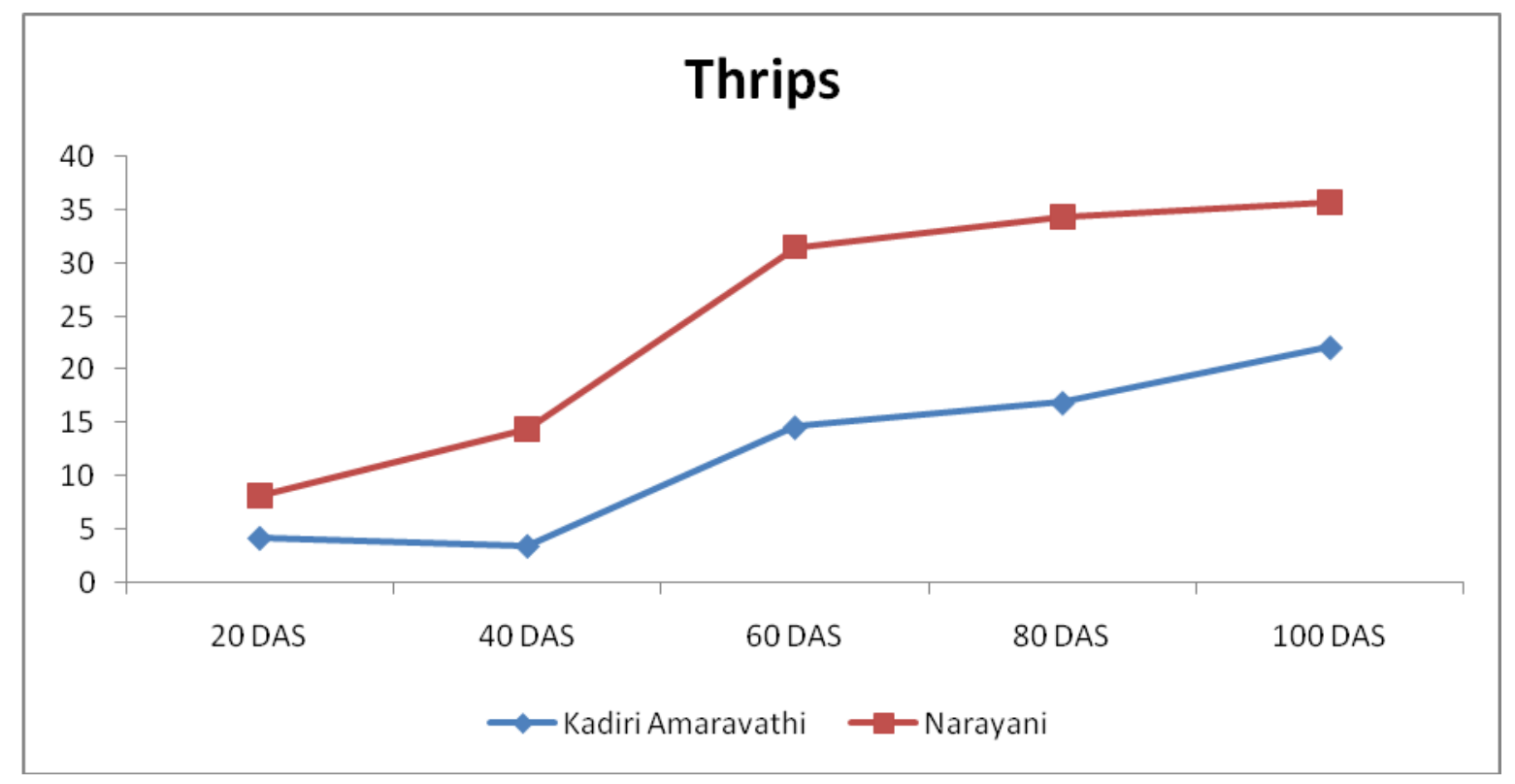

Table.2 Percent damage by peanut bud necrosis disease

\begin{tabular}{|l|c|c|c|c|c|c|}
\hline \multirow{2}{*}{ Days } & \multicolumn{3}{|c|}{ Mean } & \multicolumn{3}{c|}{ Std. Deviation } \\
\cline { 2 - 7 } & $\begin{array}{c}\text { Kadiri } \\
\text { Amaravathi }\end{array}$ & Narayani & Total & $\begin{array}{c}\text { Kadiri } \\
\text { Amaravathi }\end{array}$ & Narayani & Total \\
\hline 20 DAS & 0.00 & 2.28 & 1.14 & 0.00 & 0.45 & 1.34 \\
\hline 40 DAS & 0.40 & 4.00 & 2.20 & 0.57 & 0.14 & 2.11 \\
\hline 60 DAS & 0.00 & 4.00 & 2.00 & 0.00 & 1.84 & 2.54 \\
\hline 80 DAS & 0.00 & 4.65 & 2.33 & 0.00 & 1.63 & 2.84 \\
\hline 100 DAS & 0.00 & 5.40 & 2.70 & 0.00 & 2.12 & 3.35 \\
\hline Average & $\mathbf{0 . 0 8}$ & $\mathbf{4 . 0 6}$ & & & & \\
\hline
\end{tabular}

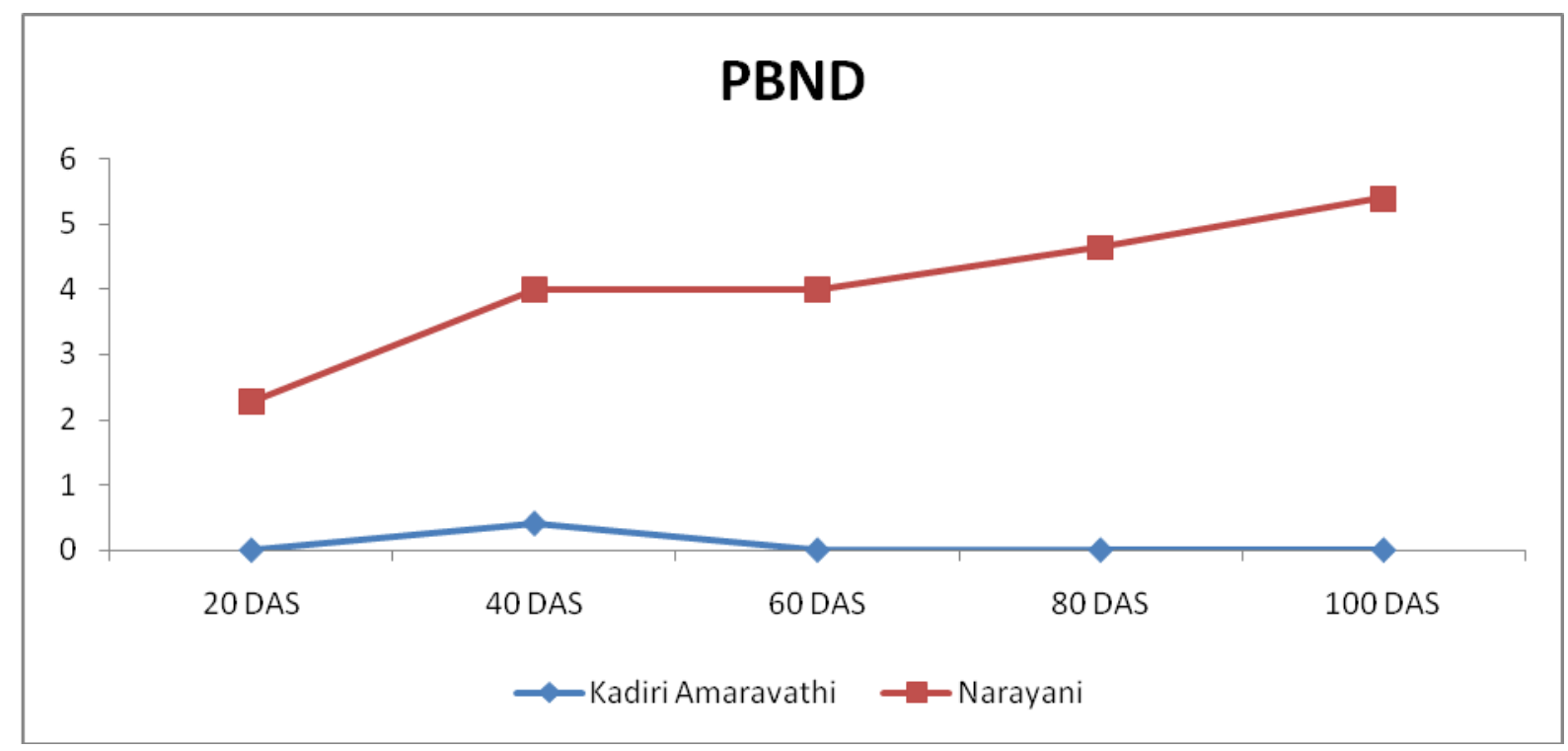


Table.3 Percent damage by peanut stem necrosis disease

\begin{tabular}{|c|c|c|c|c|c|c|}
\hline \multirow{2}{*}{ Days } & \multicolumn{3}{|c|}{ Mean } & \multicolumn{3}{|c|}{ Std. Deviation } \\
\cline { 2 - 7 } & $\begin{array}{c}\text { Kadiri } \\
\text { Amaravathi }\end{array}$ & Narayani & Total & $\begin{array}{c}\text { Kadiri } \\
\text { Amaravathi }\end{array}$ & Narayani & Total \\
\hline 20 DAS & 0.00 & 0.00 & 0.00 & 0.00 & 0.00 & 0.00 \\
\hline 40 DAS & 0.00 & 2.95 & 1.48 & 0.00 & 0.35 & 1.72 \\
\hline 60 DAS & 0.00 & 3.74 & 1.87 & 0.00 & 1.50 & 2.33 \\
\hline 80 DAS & 1.10 & 7.65 & 4.38 & 1.56 & 1.77 & 4.02 \\
\hline 100 DAS & 0.00 & 8.13 & 4.06 & 0.00 & 9.02 & 7.01 \\
\hline Average & $\mathbf{0 . 2 2}$ & $\mathbf{4 . 4 9}$ & & & & \\
\hline
\end{tabular}

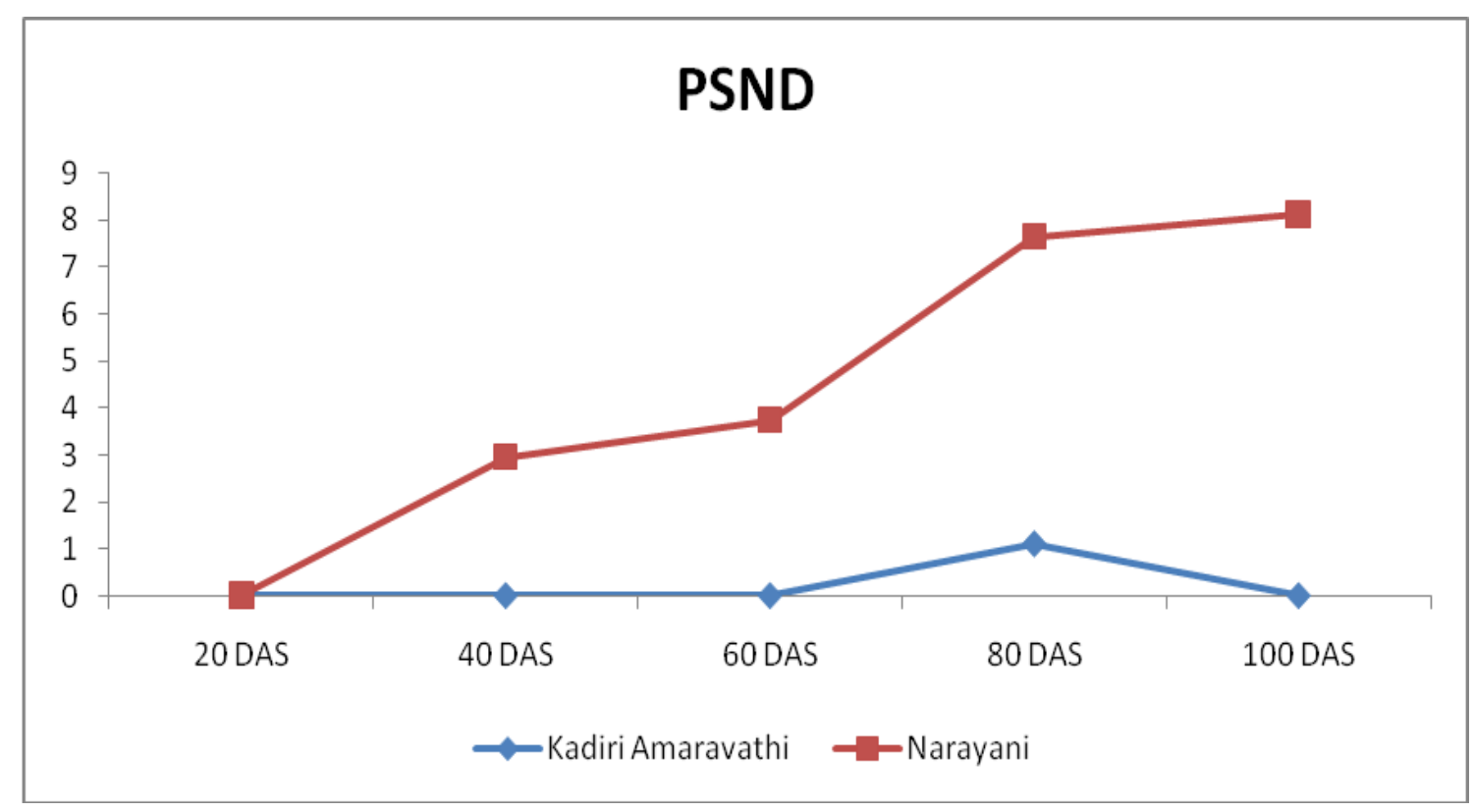

Rating scale of thrips damage in groundnut

(Source: Keerati-Kasikorn and Singha, 1986)

\begin{tabular}{|c|c|}
\hline Scale & Per cent damage \\
\hline $\mathbf{1}$ & No damage to 10\% damage \\
\hline $\mathbf{3}$ & $11-30 \%$ damage \\
\hline $\mathbf{5}$ & $31-50 \%$ damage \\
\hline $\mathbf{7}$ & $51-70 \%$ damage \\
\hline $\mathbf{9}$ & $71-100 \%$ damage \\
\hline
\end{tabular}

\section{Peanut stem necrosis disease}

In Kadiri Amaravathi variety $1.1 \%$ damage was observed at 80DAS whereas in Narayani, the damage was recorded from 40DAS to till harvest. Minimum of $2.95 \%$ and maximum of
8.13\% was recorded during the cropping period. On an average, $12.25 \%$ thrips damage was observed in Kadiri Amaravathi and $24.85 \%$ in Narayani variety. With regard to PBND and PSND incidence, $0.08 \%$ and $0.22 \%$ was recorded in Kadiri Amaravathi 
respectively. In Narayani, $4.0 \%$ and $4.49 \%$ was recorded. Though thrips incidence was recorded up to 25-30\% PBND \& PSND incidence was very low in both the varieties.

This may be due to the major vector of viral diseases i.e. Thrips palmi may not be present in the field and other thrips species caused considerable damage to groundnut. Vijaya lakshmi (1994) reported that T. palmi is the vector of PBNV of groundnut in India and $F$. schultzei and $S$. dorsalis are proved as nonvectors. Vennila et al., (2018) reported that the PBND incidence was dependent on relative humidity and prevalent wind over previous two weeks in addition to thrips abundance or infestation.

\section{Yield}

Average yield of $2500 \mathrm{~kg}$ per hectare was obtained in Groundnut variety Kadiri Amaravathi whereas in Narayani variety $3150 \mathrm{~kg}$ per hectare was recorded. Kadiri Amaravathi has recorded $20.6 \%$ lower yield than Narayani variety.

Though the variety has recorded comparatively lower incidence of thrips, PBND and PSND, average yield is less than Narayani variety. But the variety has good shelling percentage of $71 \%$ whereas Narayani recorded $65 \%$ shelling percentage.

In conclusion, groundnut variety Kadiri Amaravathi recorded low incidence of thrips and viral diseases when compared to Narayani. The variety has dark green foliage till harvesting and suitable for fodder purpose as well. But it recorded low yield when compared to local check i.e. Narayani. Duration of the variety is also high i.e. 2025days than check. The variety has good shelling percentage and it will be suitable to the areas where irrigation facility is available and PBND \& PSND incidence is severe.

\section{References}

Amin, P.W. 1985. Apparent resistance of groundnut cultivar Robot 33-1 to bud necrosis disease. Plant dis. 69:718-719.

Anon. 2017. Agricultural Statistics at a Glance. Directorate of Economics and Statistics, Department of Agriculture and Cooperation and Farmer's Welfare, Government of India.

Daughtrey, M.L., R.K. Jones, J.W. Moyer, M.E. Daub and J.R. Baker 1997. Tospovirus strike the greenhouse industry: INSV has become a major pathogen on flower crops. Plant Dis., 81: $1220-1230$

Dwivedi, S.L., Reddy, D.V.R., Nigam, S.N., Rao, G.V.R., Wightman, J.A., Amin, P.W., Nagabhushanam, G.V.S., Reddy, A.G.S., Scholberg, E., Ramraj, V.M. 1993. Registration of ICGV 86031 peanut Germplasm. Crop Science. 36:220

Ghanekar, A.M., Reddy, D.V.R., Iizuka, N., Amin, P.W. and Gibbone, R.W. 1979. Bud necrosis in groundnut (Arachis hypogaea) in India caused by Tomato spotted wilt virus. Ann. Appl. Biol., 93: 173-179.

Ghewande, M. P., Desai, S. and Basu, M. S. 2002. Diagnosis and management of major disease of groundnut. Proceedings of a meet September 2002. NRCG, Junagadh, Gujarat 13-14.

Ghewande, M.P. 1987. Virus diseases of groundnut and their management. In: "Symposium on diseases of oilseed and pulse crops and their control". pp. 6267. (Jawaharlal Nehru Krishi Vishwa Vidhyalaya, Indore, M.P.).

Gopal, K., and Upadhyaya, H.D.1988. Effect of bud necrosis disease on yield of groundnut (Arachis hypogaea L.) Indian Phytopathol. 32: 122-123.

Harish, G. M.V., Nataraja, Poonam Jasrotia, Prasanna Holajjer, S.D., Savaliya and 
Meera Gajera 2014. Impact of weather on the occurrence pattern of insect pests on groundnut. Legume Research 38 (4): 524-535.

Immaraju, J.A., T.D. Paine, J.A. Bethke, K.L. Robb and J.P. Newman. 1992. Western flower thrips (Thysanoptera: Thripidae) resistance to insecticides in costal California greenhouses. Journal of Economic Entomology, 83: 9-14

Keerati - Kasikorn, M. and P. Singha 1986. Evaluation of groundnut lines for insect resistances. Proceedings of the $6^{\text {th }}$ Thailand National groundnut meeting, Mar.18-20, Prince of Songkla University, Songkla and the talibun national park, Satul, pp: 13-17.

Nandagopal, V., and Vasanta, S. 1991. Influence of plant growth regulators on the population of thrips, Caliothrips indicus (Bagnall) and damage in groundnut. Entomon, 16: 87-89.

Ranga Rao, G.V., and Wightman, J.A. 1993. Groundnut thrips of economic importance, their occurrence and seasonal distribution. J. Entomol. Sci., 4: 13 .

Reddy, D.V.R.., Amin, P.W., Mc Donald, D. and Ghanekar, A.M. 1983. Epidemiology and control of groundnut bud necrosis and other diseases of legume crops in India caused by tomato spotted wilt virus. In: Plant Virus Disease Epidemiology. (Eds., Eastop U.C., Plums, R.T. and Thresh, J.R.) pp. 93-102. Blackwell Scientific Publication Ltd., Oxford.
Ulman, D.E., Sherwood, J.L., German, T. L. 1997. Thrips as vectors of plant pathogens. In T. Lewis (ed), Thrips as Crop Pests.CAB International, New York, pp. 539-565.

Vennila, S., Ranjit Kumar Paul, M.N. Bhat, S.K. Yadav, K. Vemana, E. Chandrayudu, S. Nisar, Murari Kumar, Ankur Tomar, M.Srinivasa Rao and M. Prabhakar 2018. Abundance, infestation and disease transmission by thrips on groundnut as influenced by climatic variability at Kadiri, Andhra Pradesh. Journal of Agrometeorology 20 (3): 227-233.

Vijaya lakshmi, G., Ganapathy, N., and Kennedy, J.S. 2017. Influence of weather parameters on seasonal incidence of thrips and Groundnut bud necrosis virus (GBNV) in groundnut (Arachis hypogea L.) Journal of Entomology and Zoology Studies; 5(3): 107-110

Vijaya lakshmi, K. 1994. Doctoral Thesis on Transmission and Ecology of Thrips palmi Karny, the vector of Peanut Bud Necrosis Virus submitted to Andhra Pradesh Agricultural University.

Vijayalakshmi, K., Reddy Raji, D., Verma, N.R.G and Pranuthi 2009. Weather based pests \& disease forewarning models in groundnut in the context of climate change. Proceedings workshop on Impact of climate change on Agriculture, ISPRS Archives XXXVIII 8/w3 pp: 48-50.

\section{How to cite this article:}

Prasanna Lakshmi, R., P. Ganesh Kumar, P. Lavanya Kumari, M. Reddi kumar and Kishan Tej, M. 2019. Assessment of PBND and PSND Tolerant Groundnut Variety Kadiri Amaravathi. Int.J.Curr.Microbiol.App.Sci. 8(06): 1514-1520. doi: https://doi.org/10.20546/ijcmas.2019.806.182 